\title{
Government-Sector Unionism and Human Rights
}

\author{
Charles W. Baird
}

Published online: 31 July 2012

(C) Springer Science+Business Media B.V. 2012

In my view, the recent flurry of attempts by various state governors and legislatures to reign in collective bargaining "rights" among government-sector employees violates no one's rights, correctly understood. Moreover, collective bargaining for government-sector employees violates the rights of both government-sector workers and taxpayers.

First, I will clarify the meaning of voluntary exchange, human rights, and freedom of association. Then I will apply these concepts to government-sector collective bargaining.

\section{Voluntary Exchange: Rights in Process}

An exchange is a reciprocal giving and receiving of goods and services among two or more people. An exchange is voluntary if four criteria are met (Baird 1988):

a. Entitlement. All parties to the exchange must either own that which they are offering to exchange, or they must be acting as the authorized agent of the owner (s). There is no such thing as voluntary exchange of stolen property.

b. Consent. All parties to the exchange must agree to (1) enter into the exchange relationship - i.e., to bargain with each other-and (2) the terms at which any actual exchange takes place-i.e., the final outcome of the bargaining. No forced bargaining can result in a voluntary exchange contract.

c. Escape. All parties to the exchange must be able to turn down any offers they do not like and walk away without losing anything to which they are entitled. This is really implicit in the consent criterion, but I state it as a separate criterion for emphasis.

Thanks to Douglas B. Rasmussen for helpful comments

C. W. Baird $(\triangle)$

College of Business and Economics, California State University, East Bay, Hayward, CA 94542, USA

e-mail: charles.baird@csueastbay.edu 
d. No misrepresentation. No party to the exchange may defraud any other parties. That is, no one can tell a lie. This leaves room for honest error. I can make any claim that I believe to be true when I make it, even if it turns out later to be incorrect. Moreover, this criterion does not require the parties to tell all they know. It merely proscribes any person saying something he knows to be false. In the market, competition and entrepreneurship tend to ferret out and correct error (Kirzner, 1973).

Hayek $(1960,1973)$ often asserted that the primary responsibility of government in a free society is to enforce the "universal rules of just conduct." I suggest that those rules are nothing more or less than the rules of voluntary exchange. In voluntary exchange, no person's ends are forcibly subordinated to the ends of others. No person can, without his consent, be used as a means to satisfy any other person's ends. Such consent can only be obtained by some form of acceptable compensation.

\section{Getting Rights Right}

If something is a human right, it must be possible for all humans to exercise it in the same way, at the same time, without logical contradiction. If when an alleged right is exercised by Person A, the ability of Person B to do the same is precluded or impaired, the alleged right is a Person A right, not a human right. In other words, a true human right is one that can be exercised by all humans non-rivalrously. ${ }^{1}$

Philosophers usually refer to non-rivalrous rights as "negative" rights because the exercise of the right by anyone imposes an obligation on others not to interfere. Non-rivalrous rights are not created by politicians or anyone else. They are our birthright. Jefferson called them "unalienable"-all humans hold them, as a gift of the Creator or by virtue of their nature, simply because they are humans. They are, as some would have it, our "natural" rights. Others call them "inherent" rights. In Jefferson's words, the purpose of government is "to secure these rights."

The rights delineated in the U. S. Declaration of Independence are nonrivalrous. For example, the right to pursue happiness, within the context of voluntary exchange, can be exercised by all without conflict or contradiction. We can all pursue our happiness by making voluntary exchange offers to others which they are free to accept or reject in the pursuit of their happiness.

In contrast, there is no right to achieve happiness in the sense that anyone is guaranteed to succeed in his pursuit of happiness. If I had a right to achieve happiness there would have to be some others who have an obligation to provide me with the means necessary to guarantee my success. In that case, my exercise of the right to achieve happiness would be in conflict (rivalry) with their right to achieve their happiness. They would have fewer of their own means to pursue their own

\footnotetext{
${ }^{1}$ A successful job applicant may be said to "preclude or impair" the ability of an unsuccessful job applicant to get the job. But no right is thereby precluded or impaired. Each job applicant has a non-rivalrous right to make the best case he can for himself. Neither has a right to the job without the consent of the employer.
} 
happiness. Taking resources from others without their consent is involuntary exchange.

Philosophers usually refer to rivalrous rights claims as "positive" rights because the exercise of such a right by Person A imposes on Person B the affirmative obligation to provide Person A with the means to achieve success. Politicians are very fond of enacting positive rights - i.e., giving some people legal, but not natural, claims to the resources of others. Such is the nature of rivalry in rights.

President Obama (2001) has opined that the US Constitution is incomplete because it tells us what government cannot do to us, but it does not specify what government must do on our behalf. However, if the Constitution specified what the government must do on our behalf, beyond securing our non-rivalrous rights, it would have to specify who has what legal rights to the resources of which others. Government has no resources apart from those taken from individuals subject to its rule. Equality before the law in the exercise of positive rights is impossible. A government that takes from Person $\mathrm{A}$ to give to Person $\mathrm{B}$, does not treat $\mathrm{A}$ and $\mathrm{B}$ equally.

\section{Freedom of Association}

If freedom of association is a legitimate human right its application in practice must have two parts. Person A is free to associate with any other Person B, or group of persons. This is often called the "positive" aspect of freedom of association. ${ }^{2}$ But suppose Person B does not want to associate with Person A. If Person A's positive freedom of association confers on Person B the duty to associate with Person A, Person B does not have freedom of association. Person B's association is compelled. Person A would have a rivalrous right of association with Person B. Correctly understood, Person A's freedom of association is the right to associate with any other person (or group of persons) who is willing to associate with Person A.

Both Person A and Person B have a right to decline association with each other and with anyone else. This is often called the "negative" aspect of freedom of association. It gives each person the right to say "no." Free association requires mutual consent.

There are not two freedoms of association: one positive the other negative. Rather, there is one freedom of association that, to make sense, must include the right to accept and the right to reject association. When both the positive and negative aspects of freedom of association are in force, freedom of association is a non-rivalrous right.

Article 20 of the United Nations Declaration of Human Rights (1948) states

(1) Everyone has the right to freedom of peaceful assembly and association.

(2) No one may be compelled to belong to an association.

Therefore, every form of coerced association violates human rights.

\footnotetext{
${ }^{2}$ The terms "positive" and "negative" when applied to freedom of association do not mean the same as when they are applied to rights. Here, "positive" means the right to accept association, and "negative" means the right to decline association.
} 


\section{Government-Sector Unionism}

This paper is not about private-sector unionism, the rules for which are contained in the National Labor Relations Act (NLRA, 1935, amended in 1947). However the various state and local statutes that specify the rules for government-sector unionism are patterned on the NLRA.

\section{Exclusive Representation, Union Security, and Mandatory Good-Faith Bargaining}

There are no non-rivalrous rights to exclusive representation, union security, or mandatory good faith bargaining as defined in the NLRA and its state and local clones. All three of these government-imposed institutions violate freedom of association. The violations are especially egregious in government sector employment

\section{Exclusive Representation}

Section 9(a) of the NLRA imposes "exclusive representation" (monopoly bargaining) on employees and employers. If, in a certification election, a majority of workers in a bargaining unit vote to be represented by Union A, then all the workers who were eligible to vote must submit to those representation services. Union A, perforce, represents the workers who voted for it; but it also represents the workers who voted for another union, the workers who voted to remain union-free, and the workers who did not vote. It is a winner-take-all election. Individuals are prohibited even from representing themselves on terms and conditions of employment and other matters that come under "the scope of collective bargaining." Employers may not deal directly with individual workers. Individual workers have no voice. Only a certified union may speak.

In the private sector, without any government force, an employer should be free to choose to run his enterprise on the basis of exclusive representation by any union he chooses made up entirely of voluntary members. The problem is not exclusive representation itself. The problem is that the government violates human rights by mandating exclusive representation.

Government-mandated exclusive representation is a violation of the entitlement condition for voluntary exchange. It implies that an individual does not own his labor. Rather, by force of law, a majority of his colleagues own it. It is a violation of a dissenting worker's freedom of association. Freedom of association forbids any kind of forced association, even by majority vote.

Unionists justify exclusive representation by analogy to elections of politicians. In a congressional election, the winning candidate is the exclusive representative of all voters in the district. Those who voted against her and those who did not vote must accept the winning candidate as their exclusive representative in the House of Representatives. By analogy, unionists argue, it is proper to force all workers to accept the representation services of a union selected by majority vote. It is simply "workplace democracy."

Well, it is a strange form of democracy. Once a union is certified as an exclusive bargaining agent, it is presumed to have majority support indefinitely. There are no subsequent, periodic elections to test whether or not majority support continues. This 
oddity in the law has, in the private sector, created a situation in which only $10 \%$ of those represented by a union ever voted for the union (Hatch, 2011). In Wisconsin, Scott Walker and the State Legislature fixed this part of the violation of freedom of association in government-sector employment by requiring periodic, secret ballot tests of majority support.

However the larger problem of forced association through majority vote in government-sector employment remains. Unions are not governments. The Framers of the Constitution drew a bright line separating rules for decision making in government and rules for decision making in the private sphere of human action. According to the Framers, it is legitimate for the government to override individual preferences in favor of majority rule only with respect to the limited powers of government, enumerated in Article I, Section 8 of the Constitution. Everything else should be left to individuals to decide irrespective of what a majority of others may prefer. An individual is not forced to submit to the will of a majority in the choice of religion, nor should he be in the choice of a representative in the sale of his labor services. The sale of one's labor services, even to a governmental employing agency, is a quintessentially private act.

People sometimes choose to affiliate with private groups that make decisions by majority rule, but they are not coerced into doing so. They are assured that they have an easy escape without losing anything to which they are entitled. Under governmentmandated exclusive representation, the only way one may avoid the majority-rule decision to unionize is to lose her job. But she is entitled to the job so long as both she and her employer are willing to continue the employment relationship. The only reason a third party (union) has any say is because government has granted privileges (rivalrous rights) to some individuals (union officials) at the expense of others (workers who prefer to be union-free).

Exclusive representation is especially offensive in government-sector employment. It is a proclamation that the government will not associate (in the form of a voluntary exchange employment contract) with anyone of its citizens who is not represented by a private organization called a government-employee union (GEU, my favorite onomatopoeic acronym). The union is a private third party that comes between government and its citizens.

\section{Union Security}

Section 8(a)3 of the NLRA states that it is an unfair labor practice for an employer, "by discrimination in regard to hire or tenure of employment or any term or condition of employment to encourage or discourage membership in any labor organization [except the employer may] require as a condition of employment membership therein...." Imagine that. Employers may not encourage or discourage union membership, they may only agree with a union to require it.

Unions justify this coercion on the grounds that under exclusive representation they are required to represent all workers in their respective bargaining units whether individual workers want such representation or not. Thus, it is only fair that every worker must be forced to pay for that representation. Otherwise, some workers would be free riders, and unions need security from free riders. However, this alleged free-rider problem could be almost eliminated simply by repealing exclusive representation. If 
unions bargained only for their voluntary members and no one else, the only free riding that could conceivably occur would involve bargaining for job-environment enhancements such as safety. But even then apparent free-riding might be forced-riding.

The free-rider argument is based on the assumption that all workers place a positive value on union representation. However, it is likely that there are many workers who place a zero, or even negative, value on such representation. Suppose a worker values union-bargained extra safety at $\$ 100$, but places a $\$ 300$ value on being forced to be represented by the union, she would be a forced rider. Forcing her to pay union fees is like forcing a victim of vandalism to pay for the privilege of being vandalized.

In the government sector, union security amounts to the government collecting a tax from its employees which it then turns over to a private third party. Article I, Section 8 of the Constitution allows the Congress to tax people to provide for the general welfare, that is the non-rivalrous welfare of all, not rivalrous welfare gains for some (such as union officials) at the expense of others. In the government sector, forced riding amounts to theft by government at the behest of union campaign contributors. Scott Walker and the Wisconsin Legislature have done well to proscribe such violations of the rights of government employees in Wisconsin.

\section{Mandatory Good Faith Bargaining}

Sections $8(a) 5$ and 8(b)3 of the NLRA impose on employers and unions, respectively, a duty to bargain. Section $8(\mathrm{~d})$ adds that the duty is a requirement to bargain "in good faith." Case law [e.g. NLRB v. General Electric 418 F. (2d) 736 (1969)] has established that in practice, "good-faith bargaining" means that each side must compromise with the other. No take-it-or-leave-it bargaining offers may be made.

Mandatory bargaining violates the consent condition for voluntary exchange. Under ordinary contract law if any party to the contract is forced to bargain, the contract is null and void. No contract reached under the forced-bargaining rules of the NLRA and its state and local clones can be a voluntary exchange contract. Every contract reached under the forced-bargaining rules of the NLRA is an example of forced association.

Collective bargaining consistent with human rights is a union, representing only its voluntary members, bargaining on behalf of its members with an employer who agrees to bargain with the union. Both sides would be able simply to say "no" and walk away. The ordinary common law of contract would apply (Epstein 1983). Article 4 of the International Labor Organization's Convention 98 (1949) affirms that only voluntary collective bargaining is legitimate.

\section{Fourth Branch of Government and Taxation Without Representation}

In the government sector, mandatory good-faith bargaining makes unions an illicit fourth branch of government. The U. S. Constitution and each state constitution specifies three branches of government - the executive, the legislative, and the judicial. There is no mention of a fourth branch of government called government-employee unions.

Mandatory good faith bargaining is done behind closed doors with the general public having neither access nor voice. Terms and conditions of employment in the government sector are matters of public policy that have, inter alia, significant effects on taxes. The government agencies that employ government workers are typically 
part of the executive branch. Because bargaining is mandatory the executive branch is compelled to bargain with GEUs on matters of public policy. Because of "good faith" rules, the agency bureaucrats that allegedly sit on the opposite side of the collectivebargaining table from the GEUs must get the consent of the GEUs on some matters of public policy, thus the GEUs have veto power over those matters of public policy. ${ }^{3}$ In effect, the GEUs are co-equal with the executive branch of government in all matters that come under the scope of collective bargaining. They are a fourth branch of government.

Public choice theory, which one of its founders, Buchanan (2003), characterizes as "politics without romance," predicts that during government-sector collective bargaining no one represents the interests of taxpayers. The agency heads that bargain with the GEUs and the GEUs themselves have a common interest - to pick the pockets of taxpayers. The bureaucrats want larger budgets, increased power to arrange other people's lives, and better on-the-job perks. The GEUs want higher and higher wages, salaries, and retirement benefits. Politicians empower both groups in exchange for monetary and in-kind electoral support. Unorganized taxpayers are the hosts on which the parasites feed. Government-sector collective bargaining is taxation without representation.

\section{In Conclusion}

Politicians created spurious collective-bargaining rights for GEUs, so politicians are entitled (I think morally compelled) to take them away. Scott Walker et. al. violated no human rights when they reduced the privileges given to GEUs by their predecessors. Unions do not have natural rights, only humans have natural rights. Moreover, there are no "labor rights" apart from the human rights possessed by all humans-workers, investors, entrepreneurs, suppliers, customers, and layabouts. Government-sector collective bargaining is based on arbitrary privileges pretending to be human rights. It is time to put things right.

\section{References}

Baird, Charles W. (1988). "The Varieties of 'Right to Work': An Essay in Honor of W. H. Hutt," Managerial and Decision Economics, Special Issue, Winter: 33 -43.

Buchanan, James. (2003), Public Choice: The Origins and Development of a Research Program, Fairfax, VA: Center for the Study of Public Choice, George Mason University.

Epstein, Richard (1983). "A Common Law for Labor Relations: A Critique of the New Deal Labor Legislation." 92 Yale Law Journal 1357.

Hatch, Orrin (2011). "On the Introduction of the Employee Rights Act," Congressional Record, August 2. Hayek, F. A. (1960). The Constitution of Liberty, Chicago: University of Chicago Press.

Hayek, F. A. (1973) Law Legislation and Liberty, Volume 1, Rules and Order, Chicago: University of Chicago Press.

Kirzner, Israel (1973) Competition and Entrepreneurship, Chicago: University of Chicago Press. Obama, Barack (2001). Interview on Chicago Public Radio, WBEZ (http://tinyurl.com/cqm8av)

\footnotetext{
${ }^{3}$ Contrast GEUs with ordinary lobbyists such as the Sierra Club. It is not an unfair labor practice for any politician or government bureaucrat to tell the Sierra Club to get lost.
} 